\title{
Influence of Different Nitrogen Sources on the Growth and Yield of Three Varieties of Okra (Abelmoschus esculentus) in Kabba, Kogi State, Nigeria
}

\author{
Sinmidele K. Ogundare ${ }^{1 *}$, Frank D. Owa², Omolola O. Etukudo1, Naomi K. Ibitoye-Ayeni1 \\ ${ }^{1}$ College of Agriculture, Division of Agricultural Colleges, Ahmadu Bello University, Zaria, Nigeria \\ ${ }^{2}$ Department of Integrated Science, Federal College of Education, Okene, Nigeria \\ Email: drogundarekayode@yahoo.com
}

Received 30 July 2015; accepted 9 October 2015; published 12 October 2015

Copyright (C) 2015 by authors and Scientific Research Publishing Inc.

This work is licensed under the Creative Commons Attribution International License (CC BY). http://creativecommons.org/licenses/by/4.0/

(c) (i) Open Access

\section{Abstract}

Experiments were carried out at the Research Site of Horticultural Section, Kabba College of Agriculture to investigate the influence of different nitrogen sources on the growth and yield of three varieties of okra. The experiment was laid out in split block design with varieties as main plots (Lady Finger "LF", LD88 and Okele (local cultivar)) and different nitrogen sources as sub plots (Urea (108.7 kgN/ha), poultry manure (PM) $(3.01 \mathrm{t} / \mathrm{ha}=108.7 \mathrm{kgN} / \mathrm{ha})$ and cow dung (CWD) (3.83 t/ha = 108.7 kgN/ha). The treatment combinations were as follows LD88 + Urea, LD88 + PM, LD88 + CWD, LF + Urea, LF + PM and LF + CWD, Okele + Urea (108.7 kg/ha), Okele + PM and Okele + CWD. Growth parameters determined were plant height $(\mathrm{cm})$, leafarea $\left(\mathrm{cm}^{2}\right)$, number of leaves produced, stem girth $(\mathrm{cm})$, internode length $(\mathrm{cm})$ and days to $50 \%$ flowering and podding. Flower characters taken were number of flowers produced per plant, number of flowers aborted per plant, and number of pods produced per plant. Yield characters determined were individual pod weight $(\mathrm{g})$, pod length $(\mathrm{cm})$, pod diameter $(\mathrm{cm})$ and pod yield $(\mathrm{t} / \mathrm{ha})$. The data collected were subjected to analysis of variance (ANOVA) and means compared using the least significant difference (LSD) at a probability level of $5 \%$. Urea application and poultry manure had significantly different effects compared with cow dung treated plots for the parameters of growth and yield. Highest mean value was observed with urea application. This was followed by poultry manure application. The cultivar Lady's finger performed better according to the data for number of pods and fresh pod weight. This was followed by the LD88 cultivars. Okra grew taller and had bigger stem girth, greater number of leaves, larger leaf area and higher number of pods and fresh pod weight with urea application. Cultivar Lady's finger performed better than the other cultivars in most meas-

\footnotetext{
${ }^{*}$ Corresponding author.
}

How to cite this paper: Ogundare, S.K., Owa, F.D., Etukudo, O.O. and Ibitoye-Ayeni, N.K. (2015) Influence of Different Nitrogen Sources on the Growth and Yield of Three Varieties of Okra (Abelmoschus esculentus) in Kabba, Kogi State, Nigeria. Agricultural Sciences, 6, 1141-1147. http://dx.doi.org/10.4236/as.2015.610109 
ured parameters. It is therefore recommended that lady finger should be grown by farmers in the study area with their soil amended with urea fertilizer in the study area.

\title{
Keywords
}

\author{
Cultivar, Nitrogen, Poultry Manure, Cow Dung, Pod, Growth, Yield
}

\section{Introduction}

Okra (Abelmoschus esculentus L.) is an annual herb and vegetable crop grown throughout the tropical and subtropical parts of the world either as the sole crop or intercrop with maize or another crop [1]. Okra plays an important role in the human diet by supplying carbohydrate, protein, fats, minerals and vitamins that are usually deficient in the staple food. It is grown for its young leaves and green pods. Okra seeds contain about 20\% protein similar to amino acid composition of soybean protein and $20 \%$ oil (similar in fatty acid composition to cotton seed oil) [2]. The seeds however can be roasted and used as substitute for coffee [3]. The essential and nonessential amino acid which Okra contains is comparable to that of soybean [4]. Okra flowers can be very attractive and sometimes used in decorating the living rooms [5]. The nutritional importance of okra pod has reawakened interest in bringing the crop into commercial production.

Despite the nutritional value of okra, its optimum yields have not been attained in the tropical countries partly because of a continued decline in soil fertility. The nutrient requirements of crops depend upon soil texture, types of previous vegetation cover, cropping intensity and soil moisture [6]. Fertilizers are generally applied to improve the crop yield, nutritional quality and aesthetic value of crops [7]. Nutrients especially nitrogen is needed for optimum yield of cultivated crop [8]. Reasons of low yield of crops are imbalanced fertilizer use; improper nitrogen sources and high rate of leaching of the nitrogen [9]. Nitrogen is the important part of plant parts such as chlorophyll, amino acid, proteins and pigments. It is most essential for vigorous growth branching/tillering, leaf development and enlargement root expansion, high photosynthetic activity and formation of protoplasm [10]. Nitrogen fertilizers being used for vegetable production has increased by 21\% between 1997 and 2003 [11].

Nutrient imbalance and soil physical degradation hinder sustainable use of inorganic fertilizers in the tropics [12]. In order to sustain soil fertility over a long period of time, the use of organic manure is been advocated. This is because the nutrients contained in organic manures are released more slowly and are stored for a longer time in the soil, thereby ensuring a long residual effect [13]. [14] Also reported that manures provide a source of all necessary macro- and micro-nutrients in available forms, thereby improving the physical and biological properties of the soil. There are different types of nitrogen sources including cow dung, compost, green and farmyard manure etc.

Therefore, keeping in view the importance of nitrogen on growth of okra, a field research was conducted to study the influence of different nitrogen sources on the growth and yield of three varieties of okra with the objectives to find out the best nitrogen source and the best cultivar for the study area.

\section{Materials and Methods}

\subsection{Experimental Site}

The experiment was carried out for two consecutive growing seasons (2011 and 2012) at the Research Site of Horticultural Section, Kabba College of Agriculture, Kabba. The site is located at latitude of $07^{\circ} 35^{\prime} \mathrm{N}$ and longitude of $06^{\circ} 08^{\prime} \mathrm{E}$ and is $1000 \mathrm{~m}$ above sea level, in Southern Guinea Savanna Agro Ecological Zone of Nigeria, where the dry seasons are dry and hot while, wet seasons are cool. The rainfall spans between April to November with peak in June. The dry season extends from December to March. The mean annual rainfall is $1570 \mathrm{~mm}$ per annum with an annual temperature range of $18^{\circ} \mathrm{C}-32^{\circ} \mathrm{C}$. The mean relative humidity (RH) is $60 \%$. The major soil order within the experimental site is Gleysol [15]; [16]. The experiment was sited within a 14 ha agricultural field that has been mechanically tilled and cropped with tropical arable crops (maize, cowpea, sorghum, garden egg, okra, tomato and cassava) continuously for over twenty years. 


\subsection{Soil Sampling and Analysis}

In order to determine some chemical properties of the soil before the treatments were applied, 10 random soil samples were collected from the field and bulked to for a composite sample. The sample was air-dried for $48 \mathrm{hr}$ and sieved with a $2 \mathrm{~mm}$ sieve and analyzed in the laboratory for $\mathrm{N}, \mathrm{P}, \mathrm{K}, \mathrm{pH}$ and Organic carbon. Total $\mathrm{N}$ (\%) was determined by the macro-Kjeldahl method [17]. Available P (ppm) was determined using the Bray I method according to Olsen (1982). Soil $\mathrm{pH}$ values were obtained by using a HI9813-5 portable $\mathrm{pH} / \mathrm{EC} / \mathrm{TDS} /{ }^{\circ} \mathrm{C}$ meter (HANNA instruments, Romania, 2002). Soil organic carbon was determined by the Walkley-Black procedure [18].

\subsection{Field Methods}

The experiment was laid out in split block design with varieties as main plots (Lady Finger "LF", LD88 and Okele (local cultivar)) and different nitrogen sources as sub plotsUrea (108.7 kgN/ha), poultry manure (3.01 t/ha = $108.7 \mathrm{kgN} / \mathrm{ha})$ and cow dung (3.83 t/ha $=108.7 \mathrm{kgN} / \mathrm{ha})$. The treatment combinations are as follows LD88 + Urea, LD88 + PM, LD88 + CWD, LF + Urea, LF + PM and LF + CWD, Okele + Urea (108.7 kg/ha), Okele + $\mathrm{PM}$ and Okele + CWD.

The land was ploughed each year and harrowed with the aid of tractor mounted implements. Three varieties of okra were used: LD88, Lady's finger and Okele. LD88 and Lady’s finger are known to be early flowering, medium in height with nearly entire leaf margin and branches diagonally upwards at an angle of 450 with the main stem. Seeds of lady finger and LD 88 were obtained from Kogi State Agricultural Development Project (ADP) office, Aiyetoro Gbede, Nigeria. Seed of Okele cultivar was from local market at Ponyan.

Cow dung and poultry manure were applied in to the soil one week before planting while the urea fertilizer was split and applied at two and four weeks after sowing [19].

Three seeds per hole of the cultivar under trial were sown on the flat with a spacing of $0.6 \mathrm{~m} \times 0.2 .5 \mathrm{~m}$ between and within the rows respectively and later thinned to one plant/stand.

\subsection{Parameters Taken}

Growth parameters determined were plant height $(\mathrm{cm})$, leafarea $\left(\mathrm{cm}^{2}\right)$, number of leaves produced, stem girth (cm), internode length $(\mathrm{cm})$ and days to $50 \%$ flowering and podding. Flower characters taken were number of flowers produced per plant, number of flower aborted per plant, and number of pod produced per plant. Yield characters determined were individual pod weight $(\mathrm{g})$, pod length $(\mathrm{cm})$, pod diameter $(\mathrm{cm})$ and pod yield $(\mathrm{t} / \mathrm{ha})$.

\subsection{Data Analysis}

The data collected were subjected to analysis of variance (ANOVA) and means compared using the least significant difference (LSD) at a probability level of 5\% according to [20].

\section{Results and Discussion}

The Physico-chemical properties of the experimental sites are given in Table 1. Total nitrogen value in the soil was low (0.19\%). Similarly, the soil had a medium level of phosphorus $3.41 \mathrm{mg} / \mathrm{kg}$ with a corresponding low level of potassium 1.21 respectively. Relatively moderate amounts of exchangeable bases (Ca and Mg) were present in all the soil units. Organic matter was low $2.14 \%$, while the $\mathrm{pH}$ in water was slightly acidic (Table 1). Table 2 showed the chemical composition of poultry manure and cow dung used. The materials are relatively high in the essential nutrients required for the growth and development of crop.

Table 3 also showed that the results of plant height, number of leaves, leaf area were significantly increased compared to control by different nitrogen sources. The effects of the urea and poultry manure on these parameters were statistically similar and better than plots treated with cow dung. Urea however recorded the highest value in these parameters and was closely followed by poultry manure, then follow by plots with cow dung while the control plots recorded the least values. There was no significant difference in days to $50 \%$ flowering in okra due to different nitrogen sources.

The result of the growth parameters of the three okra varieties and different nitrogen sources in 2013 and 2014 is presented in Table 3 . The growth parameters were significantly affected by the okra variety and different nitrogen sources. In both years, LD88 and Lady's finger were significantly taller than the local variety. 
Table 1. pre planting soil samples.

\begin{tabular}{cc}
\hline Soil properties & Values \\
\hline Sand (\%) & 62.4 \\
Clay (\%) & 18.4 \\
Silt (\%) & 19.2 \\
Soil pH & 6.2 \\
Organic matter (\%) & 2.14 \\
Total nitrogen (\%) & 0.19 \\
Available P (mg/kg) & 3.41 \\
Available K (Cmol/kg) & 1.21 \\
Calcium (mg/kg) & 2.46 \\
Magnesium (mg/kg) & 3.36 \\
Bulk density (g/cm $\left.{ }^{2}\right)$ & 1.43 \\
Total porosity (\%) & 44.3 \\
\hline
\end{tabular}

Table 2. Composition of organic residues used in the experiment.

\begin{tabular}{ccc}
\hline Properties & Poultry manure & Cow dung \\
\hline Organic C (\%) & 38.4 & 43.4 \\
Total N (\%) & 3.61 & 2.84 \\
C/N ratio & 10.62 & 15.19 \\
Phosphorus (\%) & 1.31 & 1.14 \\
Potassium (\%) & 3.12 & 0.84 \\
Calcium (\%) & 1.24 & 1.28 \\
Magnesium (\%) & 0.34 & 0.26 \\
\hline
\end{tabular}

Table 3. Influence of different nitrogen sources on the growth character of Varieties of okra.

\begin{tabular}{|c|c|c|c|c|c|c|c|c|c|c|c|c|}
\hline \multirow[t]{2}{*}{ Organic residues } & \multicolumn{2}{|c|}{ Plant height (cm) } & \multicolumn{2}{|c|}{ Number of leaves } & \multicolumn{2}{|c|}{ Stem girth (cm) } & \multicolumn{2}{|c|}{ Leaf area $\left(\mathrm{cm}^{2}\right)$} & \multicolumn{2}{|c|}{ Internode length $(\mathrm{cm})$} & \multicolumn{2}{|c|}{$\begin{array}{c}\text { Days to } 50 \% \\
\text { flowering }\end{array}$} \\
\hline & 2013 & 2014 & 2013 & 2014 & 2013 & 2014 & 2013 & 2014 & 2013 & 2014 & 2013 & 2014 \\
\hline No application & 36.0 & 28.5 & 10.1 & 10.4 & 1.8 & 2.1 & 56.4 & 67.8 & 5.4 & 4.8 & 32.4 & 33.0 \\
\hline Urea fertilizer & 60.1 & 58.6 & 11.0 & 11.2 & 4.0 & 3.8 & 116.5 & 107.2 & 9.2 & 7.6 & 31.2 & 30.9 \\
\hline Poultry manure & 51.3 & 52.4 & 13.5 & 12.6 & 3.4 & 3.8 & 105.4 & 114.1 & 8.7 & 8.7 & 31.4 & 31.0 \\
\hline Cow dung & 46.4 & 49.6 & 12.0 & 13.1 & 3.5 & 3.8 & 92.1 & 88.4 & 7.9 & 6.3 & 30.9 & 31.5 \\
\hline LSD 0.05 & 4.21 & 3.66 & ns & 1.13 & 0.23 & ns & 12.6 & 13.8 & 0.94 & 1.33 & ns & ns \\
\hline \multicolumn{13}{|l|}{ Varieties } \\
\hline Lady’s finger & 41.1 & 47.2 & 12.0 & 13.4 & 4.1 & 3.8 & 83.4 & 93.6 & 8.3 & 8.1 & 32.3 & 31.8 \\
\hline LD88 & 50.2 & 48.5 & 12.3 & 12.8 & 4.5 & 3.8 & 106.2 & 89.1 & 9.4 & 9.1 & 30.6 & 30.7 \\
\hline Okole & 32.6 & 39.4 & 11.4 & 10.6 & 2.8 & 3.6 & 64.4 & 73.0 & 6.6 & 5.4 & 42.1 & 40.4 \\
\hline LSD 0.05 & 5.61 & 2.23 & ns & 1.14 & 0.52 & ns & 26.4 & 4.90 & 0.86 & 2.4 & 4.31 & 2.88 \\
\hline $\begin{array}{c}\text { Organic manure } \times \\
\text { variety }\end{array}$ & ns & ns & ns & ns & ns & ns & ns & ns & ns & ns & ns & ns \\
\hline
\end{tabular}


This is in conformity with the growth habits of the cultivars. LD88 and Lady's finger produced significantly larger number of leaves, more leaf area than the local cultivars. [21] observed insignificant growth parameters of LD88 and Lady's finger varieties of okra. Days to 50\% flowering were earlier inLD88 and Lady's finger compared to local variety. [22] observed that organic manure improves growth character of crop when fertilizer or manure is applied at the required amount. While, [23] reported an increase in the supply of nutrients following organic manure application.

The numbers of flowers per plant were significantly $(\mathrm{P}=0.05)$ increased by the application of different nitrogen sources (Table 4). More number of flowers was recorded in plot amend with cow dung in 2013 and in plot amend with urea in 2014. However, plot treated with cow dung recorded the largest number of flower aborted and consequently least number of pod produced. Plot treated with urea produced highest number of pod per plant in both years. Among the varieties observed, local variety had the highest number of flower in both years but produced least number of pods as a result of high rate of abortion in the flower. The varietal effect of LD88 and Lady's finger were statistically similar.

It was observed that different nitrogen sources had no significant effect on individual pod weight (g), pod length and pod diameter but there was significant effect on pod yield per hectare (Table 5). The highest number

Table 4. Influence of different nitrogen sources on the flower characters of varieties.

\begin{tabular}{|c|c|c|c|c|c|c|}
\hline \multirow[t]{2}{*}{$\begin{array}{l}\text { Organic } \\
\text { residues }\end{array}$} & \multicolumn{2}{|c|}{ Number of flowers per plant } & \multicolumn{2}{|c|}{ Number of flowers aborted per plant } & \multicolumn{2}{|c|}{ Number of pods per plant } \\
\hline & 2013 & 2014 & 2013 & 2014 & 2013 & 2014 \\
\hline Urea fertilizer & 15.8 & 18.4 & 1.2 & 4.8 & 14.6 & 13.6 \\
\hline Poultry manure & 14.4 & 15.3 & 4.0 & 4.2 & 10.4 & 11.1 \\
\hline Cow dung & 17.6 & 16.3 & 8.3 & 5.9 & 9.3 & 10.4 \\
\hline LSD 0.05 & 1.56 & 1.86 & 3.2 & 0.6 & 1.3 & 0.84 \\
\hline \multicolumn{7}{|l|}{ Varieties } \\
\hline Lady's finger & 16.2 & 14.8 & 4.1 & 2.3 & 12.41 & 12.46 \\
\hline LD88 & 15.6 & 15.6 & 4.1 & 3.6 & 11.5 & 12.0 \\
\hline Okole & 18.6 & 18.3 & 9.7 & 8.8 & 8.9 & 9.5 \\
\hline LSD 0.05 & 2.24 & 0.96 & 2.61 & 1.46 & 1.06 & 1.26 \\
\hline Organic $\times$ variety & ns & ns & ns & ns & ns & ns \\
\hline
\end{tabular}

Table 5. Influence of different nitrogen sources on the pod characters and yield of threevarieties of okra.

\begin{tabular}{|c|c|c|c|c|c|c|c|c|}
\hline \multirow[t]{2}{*}{ Organic residues } & \multicolumn{2}{|c|}{ Individual pod weight (g) } & \multicolumn{2}{|c|}{ Pod length $(\mathrm{cm})$} & \multicolumn{2}{|c|}{ Pod diameter $(\mathrm{cm})$} & \multicolumn{2}{|c|}{ Pod yield (t/ha) } \\
\hline & 2013 & 2014 & 2013 & 2014 & 2013 & 2014 & 2013 & 2014 \\
\hline Urea fertilizer & 13.4 & 12.3 & 6.3 & 6.4 & 4.83 & 4.63 & 5.83 & 5.68 \\
\hline Poultry manure & 13.8 & 11.4 & 6.0 & 6.6 & 4.21 & 4.41 & 5.33 & 5.11 \\
\hline Cow dung & 12.6 & 11.9 & 6.5 & 6.1 & 4.36 & 4.09 & 4.98 & 4.33 \\
\hline LSD 0.05 & ns & ns & ns & ns & ns & ns & 0.43 & 0.44 \\
\hline \multicolumn{9}{|l|}{ Varieties } \\
\hline Lady's finger & 12.62 & 11.66 & 7.3 & 7.6 & 5.14 & 6.31 & 6.83 & 5.48 \\
\hline LD88 & 15.98 & 14.48 & 6.1 & 5.8 & 5.84 & 5.66 & 4.16 & 4.98 \\
\hline Okole & 8.98 & 9.43 & 4.3 & 3.9 & 3.96 & 4.11 & 2.96 & 3.04 \\
\hline LSD 0.05 & 4.6 & 3.82 & 1.36 & 1.63 & 0.54 & 0.98 & 2.37 & 1.23 \\
\hline Organic $\times$ variety & ns & ns & ns & ns & ns & ns & ns & ns \\
\hline
\end{tabular}


of pod per hectare was produced by the plant receiving urea and the lowest was given by plant with cow dung application. Application of urea and poultry manure was statistically similar. [24] Also found higher number of fruits per plant by the application of urea at $120 \mathrm{~kg} \cdot \mathrm{N} / \mathrm{ha}$.

The result obtained from the studied showed that poultry manure was the richer manure compared to cow dung. [25] Reported that applications of poultry manure to the soil are necessary for a satisfactory response to okra. Poultry manure has the highest nutrient and was able to release these nutrients for okra plant competitively faster than goat and pig manure. There were significant differences among the varieties considered. Individual pod weight, pod length, pod diameter and pod yield were significantly lower in local variety compared to both Lady's finger and LD88. Though, LD88 had higher values of individual pod weight, it has lower yield compared to lady's finger in both years. The variation observed could be as a result of genetically composition of the varieties.

\section{Conclusions}

This study was designed to investigate the effect of different nutrient sources on three okra cultivars (Abelmoschus esculentus). Data were collected at different growth stages for plant height, stem girth, number of leaves, total leaf area, number of fresh pods and fresh weight of pods. In the treatment, urea application and poultry manure had significantly different effects compared with cow dung treated plots for the parameters of growth and yield. Highest mean value was observed with urea application. This was followed by poultry manure application. The cultivar Lady's finger performed better according to the data for number of pods and fresh pod weight. This was followed by the LD88 cultivars. Based on the results of this study, the following conclusion was drawn: okra grew taller and had bigger stem girth, greater number of leaves, larger leaf area, higher number of pods and fresh pod weight with urea application. Cultivar lady's finger performed better than the other cultivars in most measured parameters. It is therefore recommended that lady finger should be grown by farmers in the study area with their soil amended with urea fertilizer at rate $108.7 \mathrm{~kg} / \mathrm{ha}$. Where there is scarcity of fertilizer or available at high cost poultry manure is a good substitute.

Finally, this present study could also provide a base for further work that should encompass a wider range of varieties, while different nitrogen sources could be studied for its effect on crop performance. This work also needs to be extended to other crops and other agro-ecological zones.

\section{References}

[1] Emuh, I.F.N., Ofuoku, A.E. and Oyefia, E. (2006) Effect of Intercropping Okra (Hibiscus esclentus) with Pumpkin (Curcubita maxima Dutch ex Lam) on Some Growth Parameters and Economic Yield of Maize (Zea mays) and Maximization of Land Use in a Fadama Soil Research. Journal of Biological Sciences, 1, 50-54.

[2] Siemonsma, J.S. and Hamon, C.S. (2002) Abelmoschus caillei (A. Chev.) Stevels Record from Protabase. In: Oyen, L.P.A. and Lemmens, R.H.M.J, Eds., PROTA (Plant Resources of Tropical Africa/Resources Vegetables de l'Afrique tropicale), Wageningen,

[3] Farinde, A.O. and Owalarefe, L.B. (2007) Nigeria Fertilizer Sector, Present Situation and Future Prospects IFDC. Technical Bulletin, 12, 18.

[4] Farinde, G.C. (2007) Dry Season Vegetable Gardening. Agric Extention News Letter Information Kano, $17,7$.

[5] Schippers, R.R. (2000) African Indigenous Vegetable: An Overview of the Cultivated Species. Chaltham, UK. National Resource Institute A.C.D.E.U. Technical Centre for Agricultural and Rural Cooperation, 105-117.

[6] Denton, L. and Swarup, V. (1990) Tomato Cultivation and Its Potential in Nigeria. African Symposium on Horticultural Crops, Ibadan, 257.

[7] Sikander, A., Dawar, S., Tariq, M. and Zaki, M.J. (2009) Management of Root Diseases by Combination of Different Soils with Fertilizers. Pakistan Journal of Botany, 41, 3219-3225.

[8] Adepetu, J.A. (1986) Soil Fertility and Fertilizer Requirements in Oyo, Ogun and Ondo States of Nigeria. Produced by Federal Development of Agricultural Land Resources, 48.

[9] Akhtar, M.E., Khan, M.Z., Rashid, M.T., Ahsan, Z. and Ahmad, S. (2010) Effect of Potash Application on Yield and Quality of Tomato. Pakistan Journal of Botany, 42, 1695-1702.

[10] Khan, M.A., Sajid, M., Hussain, Z., Rab, A., Marwat, K.B., Fazal-i-Wahid and Bib, S. (2013) How nitrogen and phosphorus influence the phenology of okra. Pakistan Journal of Botany, 45, 479-482.

[11] Mubashir, M., Malik, S.A., Khan, A.A., Ansari, T.M., Wright, S., Brown, M.V. and Islam, K.R. (2010) Growth, Yield 
and Nitrate Accumulation of Irrigated Carrot and Okra in Response to Nitrogen Fertilization. Pakistan Journal of Botany, 42, 2513-2521.

[12] Ewulo, B.S., Ojeniyi, S.O. and Akanni, D.A. (2008) Effect of Poultry Manure on Selected Soil Physical and Chemical Properties, Growth, Yield and Nutrient Status of Tomato. African Journal of Agricultural Research, 3, 612-616.

[13] Sharma, A.R. and Mittra, B.N. (1991) Effect of Different Rates of Application of Organic and Nitrogen Fertilizers in a Rice-Based Cropping System. Journal of Agricultural Science, 117, 313-318. http://dx.doi.org/10.1017/S0021859600067046

[14] Abou El-Magd, M.M., Hoda, M.A. and Fawzy, Z.F. (2005) Relationships, Growth, Yield of Broccoli with Increasing N, P or K Ratio in a Mixture of NPK Fertilizers. Annals of Agricultural Science, 43, 791-805.

[15] Higgins, G.M. (1957) Preliminary Report on the Detailed Land, Soil and Contours Survey of River Rine Area of School of Agriculture, Kabba. Soil Survey Bulletin No. 31, 28 p.

[16] Babalola, T.S. (2010) Land Evaluation Studies of Two Wetland Soil in Nigeria. An MSc Thesis Submitted to the Department of Crop, Soil and Environmental Sciences, Ekiti State University, Ado Ekiti, 141.

[17] Bremner, J.M. (1982) Total Nitrogen. In: Page, A.L., Miller, R.H. and Keeny, D.R., Eds., Methods of Soil Analysis, Part 2, 2nd Edition, Agronomy Monograph No. 9, ASA and SSSA, Madison, 915-928.

[18] Nelson, D.W. and Sommers, L.E. (1982) Total Carbon, Organic Carbon and Organic Matter. In: Page, A.L., Miller, R.H. and Keenay, D.R., Eds., Methods of Soil Analysis, Part 2, ASA, Madison, 539-580.

[19] Gudugi, I.A.S. (2013) Effect of Cow Dung and Variety on the Growth and Yield of Okra (Abelmoschus esculentus (L.). European Journal of Experimental Biology, 3, 495-498.

[20] Gomez, A.K. and Gomez, A.A. (1984) Statistical Procedures for Agricultural Research. 2nd Edition, John Wiley and Sons, Inc., New York, 96-107, 199-205.

[21] Iyagba, A.G., Onuegbu, B.A. and IBE, A.E. (2012) Growth and Yield Response of Okra (Abelmoschus esculentus (L.) Moench) Varieties to Weed Interference in South-Eastern Nigeria. Global Journal of Science Frontier Research Agriculture and Veterinary Sciences, 12, 23-31.

[22] Sharma, D.H. (2004) Fundamentals of Soil Science. 7th Edition, Longman, Harlow.

[23] Grey, C. and William, V. (2006) The Right Away to Grow Fresh Vegetable All Year Round. Macmillan Publishers, London.

[24] Ahmad, F., Ishtiaq, M. and Muhammad, S. (1999) Effect of Different Levels of Nitrogen Alone and in Combination with Constant Doses of Phosphorus and Potassium on Growth and Yield of Okra cv. T-13. Sarhad Journal of Agriculture, 15, 405-407.

[25] Wevil, V.C. (2002) Quality of Horticultural Products. Butterworth and Co. (Publishers) Ltd., London. 